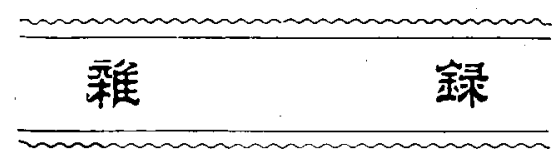

\title{
萬國工業會議 概況（2）
}

(第 11 部會提出諭文の内抄錄邦譯)

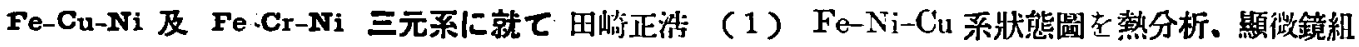
織檢定及び電氣抵抗測定に依て不形究し、Fe-Ni の邀に平行なる 9 つの斷面圖に依て固態に於ける溶 解限度區域老決定せり

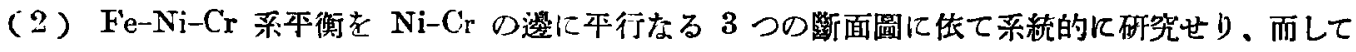
$\mathrm{Ni}-\mathrm{Cr}$ 系に於ける $1,326^{\circ} \mathrm{C}$ の共晶反應と $\mathrm{Fe}-\mathrm{Ni}$ 系に於ける $1,510^{\circ} \mathrm{C}$ の包晶反應とは本三元系に於て 命公し其結果として 2 つ均一區域 $\delta(=\alpha)$ 及び $\gamma$, 亚に不均一烦域 $\delta+\gamma$ を形成せり。

廣海軍工廠撖所

(三 島)

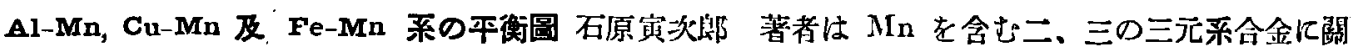
する研究を行ふ間に於て此等 3 成分金屬中の 2 者上り成る既存の 2 元平衡圆上几明に許容し難き幾多 の點あるを認め、逐に之れが再試噞を行ふでき必要に迫られたり。

而して著者の研究結果より作成せし新しき本衡圖は從來存在せる者に比し大に異る所あると共に金 相學の見地よりして合理的なるを確信す。本論文は其研究力法並に研労結果の概要を述へし者なり。

東北帝國大學教授 理學博士

(三 島)

日本に於ける货幣制度及び造幣局の沿革 殿瀨亞夫 本論文は本邦に於ける貨幣制度の發逹史並に 現在の大阪造幣局の沿革と其事業とを述べたる者なり。先づ_ト.古に於ける逝貨を逃へ天明天皇の和銅 元年に䈠造せる和銅開珍が我邦に於ける寡の貨幣の初めなりとせり，其後村上天皇 天德 2 年に至る

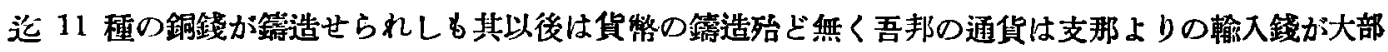
分を占めたり。然るに天正時代に至り織田信長が初めて大判金を作り、豐臣秀吉も亦多くの大判金。

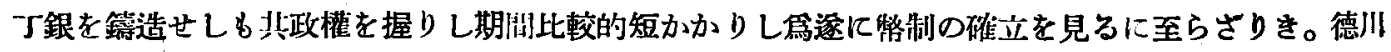

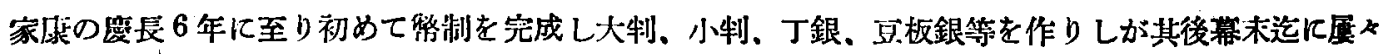

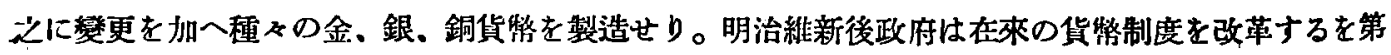

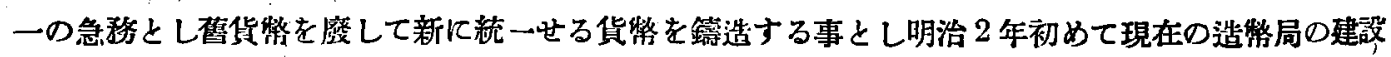

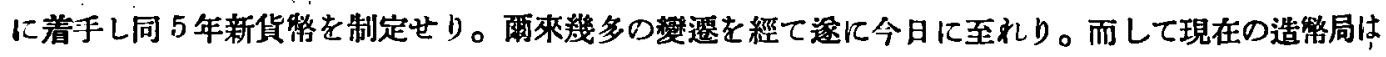

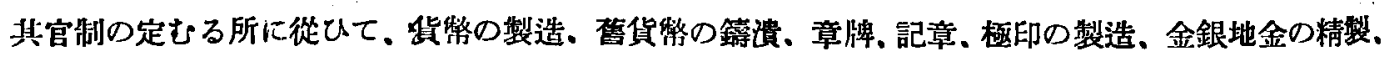
全銀合金の製造及ひ鐁物の試驗等を行ひ居れり，而して此等各項に就ては其作亲及び技術の內容を詳 逃せり。造揫局 技師 工學博士 


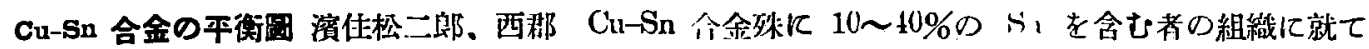

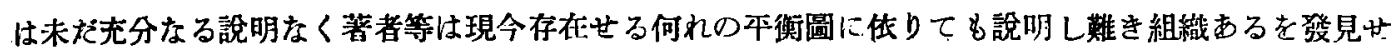
り。最近 Raper の發表せる平衡圖は此問題の解決に一步老進めをる者なれども唒充分ならざる者あ

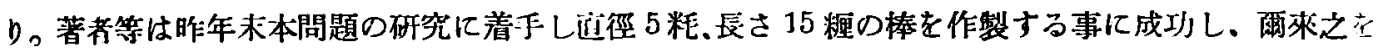

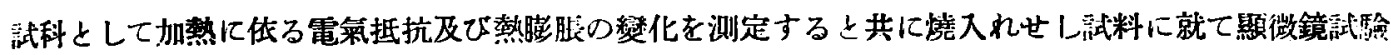
を行ひ以て固態に於ける平衡を決定せり。而して本研究の結果に依れば $\delta, \eta$ なる 2 種の化合物の存在 を認め夫ぬ $\mathrm{Cu}_{31} \mathrm{Sn}_{\mathbf{8}}, \mathrm{Cu}_{4} \mathrm{Sn}$ なる式に相賞する者とせり。前者は既に Westgren によりて指摘されL

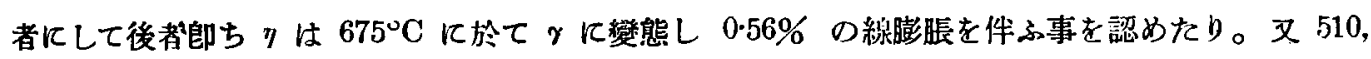
$570,630^{\circ} \mathrm{C}$ に於て 3 つの共析變態 $(\alpha+\delta, \delta+\eta-\epsilon$ 及 $\beta+\eta-\gamma$ 平術に相當す) の存在する事、及び

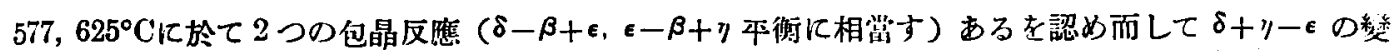
化ては $0.25 \%$ の線膨脹を伴ふ事を知れり。更に新しき相 $\epsilon$ の存在は燒入せる試料の㙷微鏡組織を檢

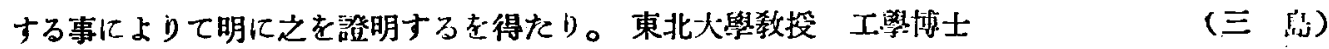

アメリカ合采國製䤡業に於ける㭖械設備 F. I. Estep. 本椧交の冈容は次の各項に就て記述せる 者なり。

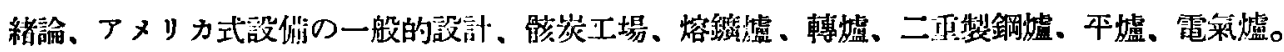

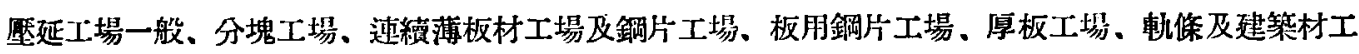
場、小形工場、線材工場、薄板工場、鑯力板工場、ストリツプ工場、製管工場、スケルプ工場、其 他。确問技師

(三 㿝)

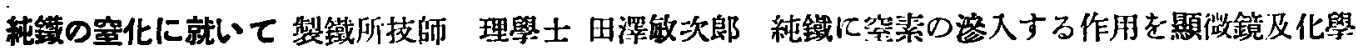
分析によつて研究した、 $30 \times 40 \times 3 \mathrm{~mm}$ の Armeo 鐵板を試料とし、アンモ=ア冞流中に於いて 670, 760 及 $600^{\circ} \mathrm{C}$ の溫度に於いて 1 50 時間熱し、曥中冷却を行つた。 $670^{\circ} \mathrm{C}$ に於て窒化せるものは

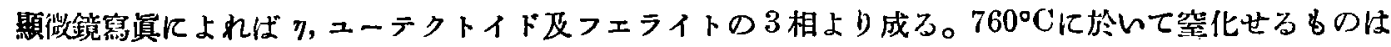

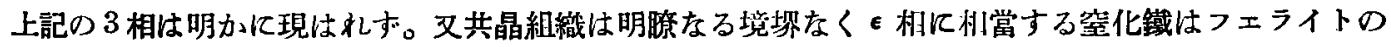

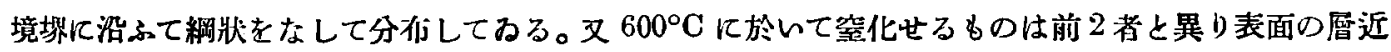

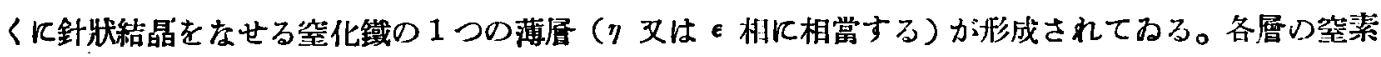
の含有量は蒸溜法によつて決定した。其結果によれば窒素は鐵板內に正絃波週期的の形にて渗入し種

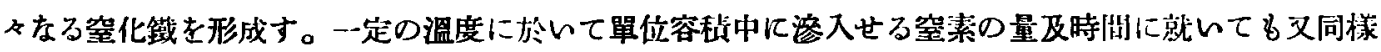
なる結果を示な。プリネル硬度數の變化も窒化鐵の愿の深さに比例する。

(海老原)

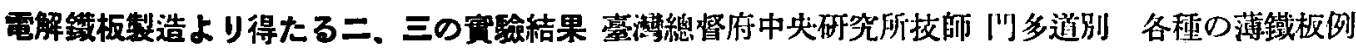

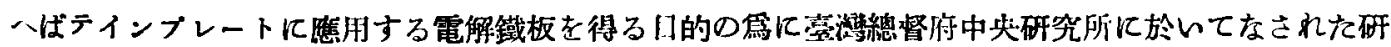

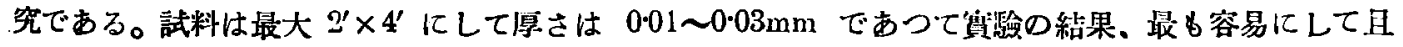

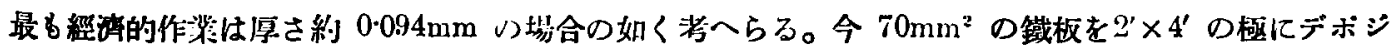


ツトせる場合の電力及材料の消費量を示せば次の樣である。

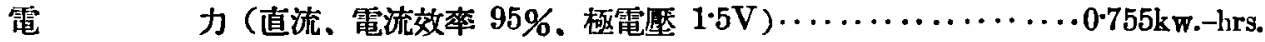

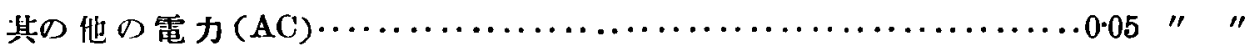

鐵

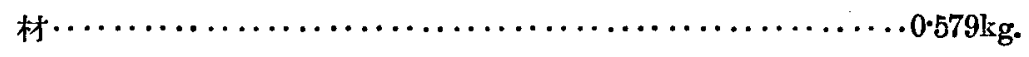

硫

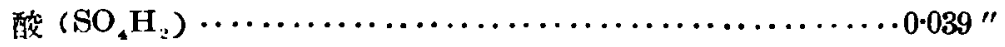

燃

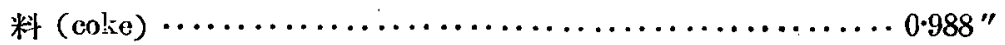

(海老原)

永久磁石鋼のエージング J.E. Gould 燒入せる永久磁石鋼が $0 〜 150^{\circ} \mathrm{C}$ の溫度に於いてェージ ングをなす際に生する變化の研究である。3 種の代表的の銅師ち水にて燒入せる 6\% タングステン

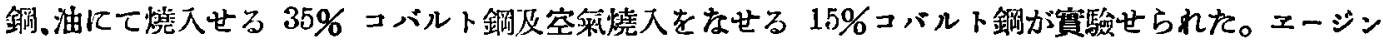
グによつて枝人感應度及殘留磁氣は增加し碩性力及 $\mathrm{BH}_{\max }$ は減少す。乙れ等の變化は焼入後始めは 急速に漸次指數国數的に逐には溫度によつて定まれる一定の極限值に達す。變化の總量はェージング の溫度と共に堭加し、常溫に於てはタングステン鋼が最小にして、35\% コバルト鋼が最大でる。 此等の變化はコロイドの溶液に於て常に行はる」如く部分的の再結晶によるものと考へられる。侣爟 入鋼とコロイドとの間の一般的關係か論議せられてるる。

(海老原)

鐵-マンガン合金の ヌ線的研究 東北帝大助敉授、理學士 大澤與芙 鐵-マンガン系の合金に就レて 其全體の組成分について X 線分析を行つた。0〜 50\% Mn を含む合金については硬度及比重の測定を も同時に行つた。測定の結果より $\alpha$ 及 $\beta$ マンガン.中心立方體の相 ( $\alpha$ 鐵) 及六方晶形の相 $\left(\mathrm{Fe}_{5}\right.$ Mn）の4 相が見出された。立分なる高溫度に於いては全細成分を通して $\boldsymbol{\gamma}$ 鐵及 $\boldsymbol{\gamma}$ マンガンの固溶體

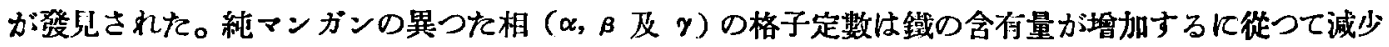
す然るに鐵に於んては其の相 $(\alpha, \gamma)$ の格子定数はマンガンの念侍量と共に僅か增加するのみである。

(海老原)

二三の鐵合金に於ける燒入硬化に就いて 理學博士 松下德次郎、日本特殊鋼技師 永澤 清 低炭 素クローム鋼の反淬機構に就いて㹸入鋼の反淬は 2 段よりなる事が發見せられた。郎ち第 1 は $300^{\circ} \mathrm{C}$ 以下，第こは 500〜 $600^{\circ} \mathrm{C}$ てて起る。前者は炭化クロームの凝結によつて物理的の變化を柬し後者は 物理的及機栈的の變化に上つて特性づけられる。實驗の結果 $500 \sim 600^{\circ} \mathrm{C}$ に於ける變化はクローム 14\%以下の鐵クローム合金に固有の性質である。燒入によつて其の硬度は著しく增扣し而して反济に よつては便度は主として 500〜 $650^{\circ} \mathrm{C} に$ 於いて減少す。同樣なる實驗が他の合金郎ち $\mathrm{Fe}-\mathrm{Va}, \mathrm{Fe}-\mathrm{Mo}$ 及 $\mathrm{Fc}-W$ の合金に於いても見出された。燒入に於ける硬化機構は炭素鋼に於ける本多博士の理諭に よつて䛸明せられる。

（海老原）

世界に於ける鐵籍の供給 C.K. I . eith （米國ウイスコンシン大學地質學科教授）本諭文は先づ最

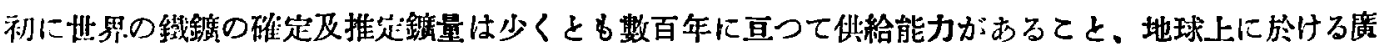


き賦存の狀况、特に西歐に集中して居る狀沉及此地方の將來に於ける大堆產の見込、過去の發達が比

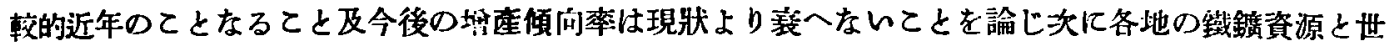
界鐵銅生產狀沉との關係に及び著者は鐵鍽業の將來の大中心地は多分北大西洋岸であるとなし之に次 くものは溹洲、南阿、印度、ロシャ等であらうと論じて居る。

將來の資源發見．其利用價值を左右する條作、鐵鋼の將來の利用及其商咩上の統制に關して特に力 說した、結論としては鐵鑛資源の所在地（地理的又は商業的）に關し附隨する軍事的政治的關係に則 する所論を述べ英、米、獨。佛の座業建設に貢献した産業革命に於ける鐵及鋼の役割を想へば北大西 洋岸に斯る强國の集中したてとが鐵鋼業に重大なる關係の有る限り世界の他の部に之と同一事例を求 むるととは出來ないと論じて居る。

(足 立)

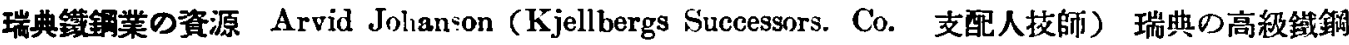

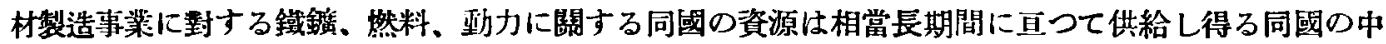
部 Bergslagen には䗲及硫黃分低き鑛石が多量にあつて木岑燃料による純鐵鋼の製造に適する北部に は同梾な鐿床があつて電氣製煉に適する。木炭の供給には限度があるが現在の實需に對しては不足し

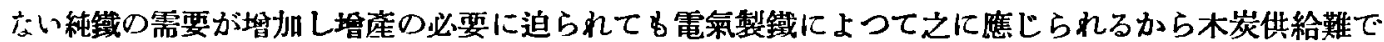
行詰ることはない、動力としての電力は瑞典慗鐵銅事業に非常な重要性を持つ、現在をでは Bergslagen 水路から得て居たが將來の需要罩加に對しては Norrland の諸河からの電力を輸送しなければ なら妨らら。

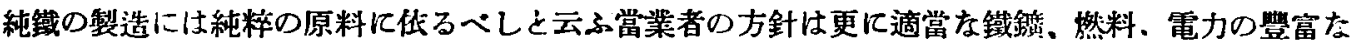

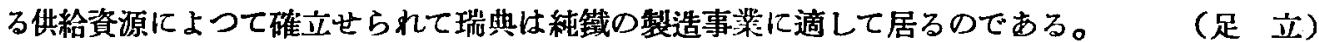

日本に於ける壓延事業の發達 永田五郎 （八幡製鐵所條鈉部長） 本邦の塺延事業の歴史は 30 有 除年である。郎ち八幡製鐵所で事亚を開始したのが其初めである(1901年) 當時の捱延品の輸入は年

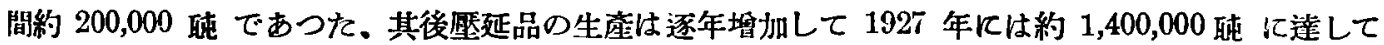
居るが台鐱入は約 810,000 䣩である。本邦で用るて居る壓延機の種類は次の通门である。
1. 牛製品ミル
2. 軌條及大形ミ儿
3. 中形ミル
4. 小形ミル
5. 線材ミれ

6. 厚板:ル

7. 薄板ミル

8. 銓管タイヤミル等

(足 立)

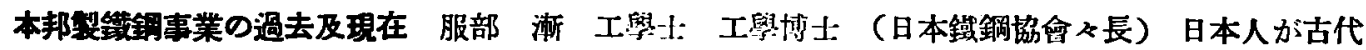
加鐵の利用を知つて居たてとは神話に体つても察しられる、中世代に於ける刀劍製造法は世界有 名な事實である、當時は專ら砂鐵を原料として簡單な作拝によつて裝造した、八幡製鐵所其他の設立 は斯畒の著しい發展の源で極めて近年のてとである、著者は日下急激な發展の道程にある本邦製鐵銅

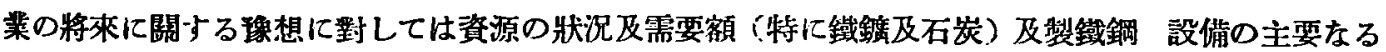
るのに就て述でるを便よして論して居る。(省略)

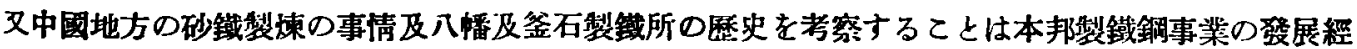




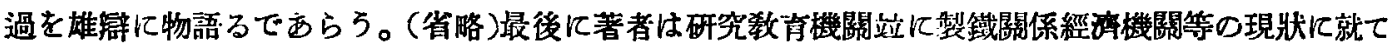
进べて居る。(本誌笨一號に全文あり）(足立)

日本に於ける製銑業の發達 八幡製鐵所銑鐵部長 䲸清新五 本邦には古來から鉄鐵の製造が行は れたが需要も少かつたから 19 世紀末までは盃んではなかつた。製鐵業の進步は鎖國主義に禍されて 甚だ遲れた。高婋が初めて 使用せられたのは 1880 年であるが、賽際現在の役展の基となつたのは 1896年八幡製鐵所の設立に源を發する、歐洲大戰中の鐵鋼材缺乏は斯咩を大に刺钱し約 200 の場が 出來た其後之等は著しく整理された、官民は共に自粭自足を標準として努カして居る最近の銑鐵產額 は約 1,514,751 䣩で需要の 79.7\% である。

日本の鐵鋠資源は平時稼行するには不利の篇朝鮮、支那、馬來牛島から鐱入して居る、高爈用とし て好適な䯚炭原料炭に付ても重大な問題がある、之が高譃作業の發澾を掘れさしたが最近では設䍀作 業共外國に比して大なる見劣りしないと信する。

近年鉄銅一貫作業が高調せられる样になつた。合金鐵は年間 約 16,000 訧の生産があつて需要の約 76\% を倛給して居る。

(足 立)

合金鋼の工業的應用に於ける最近の進步 Sir Robert A. Hadfield 本諭文は過去數年間に於ける合

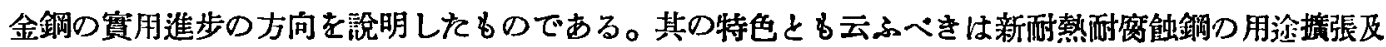
之が工業設計上に與へた刺皒である。本論文には 16 枚の圖面が添附されてるる。（时中）

鐵鋼の腐蝕の機構の要點 藤原唯莪 鐵の零蝕は 2 階段に進むものと認められる。第一段に於ては 腐蝕は電篓的方法によつて始まり進行するが第 2 段に於ては主として化學的方法に作る。水が解離し て水素イオンを生する。此水素イオンは鐵作用して之を溶解する。發生した水素は分極作用を起し て鐵の溶解は止まる。鐵は再び溶解して第一水酸化鐵が生する。此水酸化鐵の 1 . 部は鐵の保熦膜とな り、鐵は再び溶解が止まる。第一水酸化鐵の殘部は水中に溶解せる酸素により酸化せられて第二水酸 化鐵になり之が錆として沈澱する。アルカリ性である保護膜は炭酸によつて中和されて第一紫酸瀻を 生じ逐に錆となる。水素イオンは同样にして更に新しく鐵に作用する。

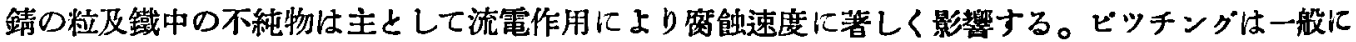
浱淡電池作用の結果である。此の場合錆の下の鐵は酸素濃度の低いために陽極になるのである。

(田 中)

銅に於ける白點の生因に就て C. Benedicks and H. Löfquist ある種の合金鋼殊にニツケルクロー ム鋼によく現はれる一種の內部裂訿をる白點の研究をしたものでする。

本研究の姴點は多くの從來の論文に現れた意見と同樣である。けれども從來認められなかつた次の

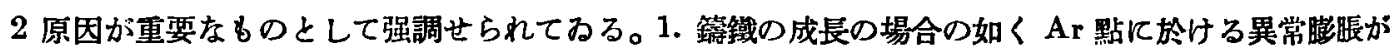

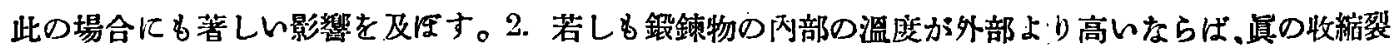
㾟が一般に牛徑方向に發生するであららと云ふ事が明瞭にされた。此事は䝷地に於ける例證で說明せ 
られた，而して理論的總括及筫際的の結論が求められた。

（时中）

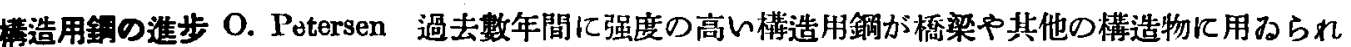
る粎になつた。此の進步は主として近來橋梁の設計に大きなスパンを用るる样になり從柬の鋼では不 適當となつたからである。過去數十年間彆鋼法發澾の結果は抗張力 37 乃至 $45 \mathrm{~kg} / \mathrm{mm}^{2}$ の鋼を造る 样になり此の種の銅が製造上最も簡單經濟的と云ふ事になつてねた。然るに更に强度の高い銅を要求 せられる样になつて第一に現れたものは炭素量を增した炭素鋼で抗張力 48 乃至 $56 \mathrm{~kg} / \mathrm{mm}^{2}$ を持つて わた。けれども之以上强度の增加は延伸の減少のため純炭素鋼では目的考羍せられなかつた。一方で 設計者は降伏點の高い事を重要視する樣になつた。併し技術上及經湾上此要求は容易に滿たされなか つた。此等の要求に應するてめに現れたものは珪素鋼であつたが穗るの缺點を持つて居た。其缺點を

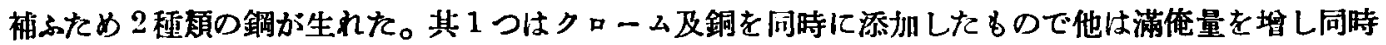
に銅或はモリブデンを加へをものである。此等の銅は獨逸で St 52 をる記號を附せられ抗張力 52乃 至 $62 \mathrm{~kg} / \mathrm{mm}^{2}$ 、降伏點 $35 \mathrm{~kg} / \mathrm{mm}^{2}$ 以上、延伸率 $100 \mathrm{rm}$ にて 20\% を有してねる。（田中）

銅の燒戻脆性に就て (蒔田宗方) 鋼の燒杘脆性は $A_{1}$ 點以下の溶解度曲線に於て柆子界に分蜼さ れる炭化物に基く事が既に發見され、而して燒厌脆性に關する種々の現象が此の理論によつて說明さ れてなる。けれども或称の現象は此理論（之を著者は第一原因上命名しやら）丈で解決されない事を 念頭に置いて著者は此の所謂第二原因を發見した。

第二原因は燒入の場合に $A_{3}$ 點以上の如き高溫加熱に基を、第一原因は燒杘り場合の影響によるの である。䞒の甚しい燒㞔脆性は主として第二原因にょるのであつて、A 點以下の炭化物の著しい溶 解度に上るのでもなく又從來考へられた如く炭化物の特性に上るのでもない。此等の 2 原因に上り㗁

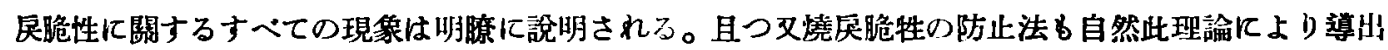
される。郎ち代冷撓杘は周知の如く第一原因を除くし。低溫燒入は第二原因による有害作用を除去し 鋼に多大の勒性を與へる。

(田中)

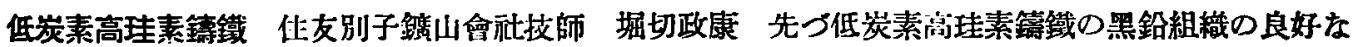

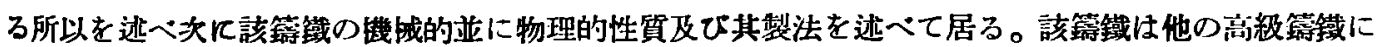
比して機械的並に物理的性質は良好にして大なる且椱雜なる篟物に於てる均一なる組織を有し、又凝

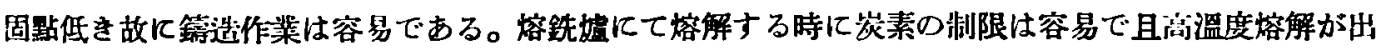
來る利益がある。

(四中)

一䣬化炭素炭酸瓦斯湜合瓦斯に传る含チタン鐵籍の罢元速度に及ぼす溫度。瓦斯成分及び砂鐵粒の 影整 東北帝國大學教投金属研究所 岩瀨久筬 (II) 中)

白銑鐵の黑鉛化を促与種々の方法 京都帝國大學助教授 摆怗 宏 著者は先づ黑鉛化に及任す各 元素の影饗に就て研究し次に瓦斯の影管に於て研究し炭酸瓦斯は然鉛化を促進し水素瓦斯は之を阻止

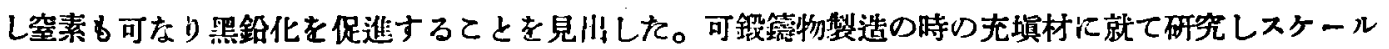




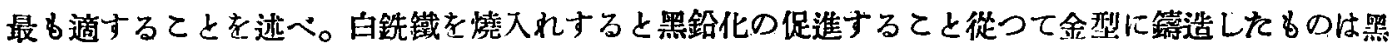
鉛化が促進する。

(因中)

日本産沼鐵籍の治金鼠的研究 輪西製鐵所 理學士川口正名 沼鐵鈸は日本に於ては主要なる鐵

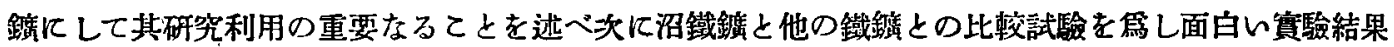
を述べてある。

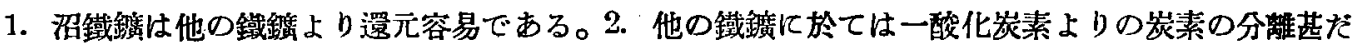

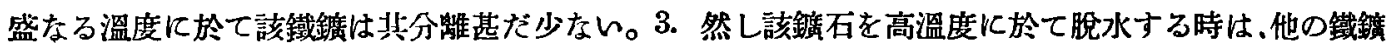

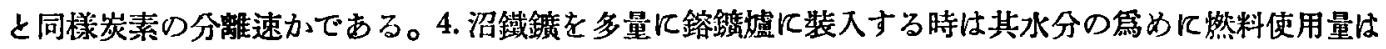

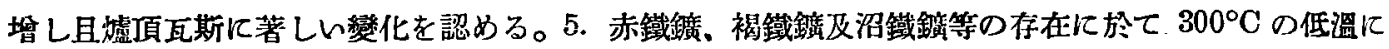

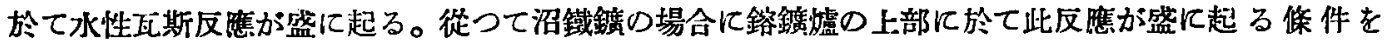
怵へて居る。6. 沼鐵鈸を $500^{\circ} \mathrm{C}$ 以下で脫水したるるのは水分の吸收速かである此方法を利用すれば 揆風乾燥が容易に且康價に出來る。7. 該鐵鏙中心燐分は苛性加里溶液に溶解する $500^{\circ} \mathrm{C}$ 以下で脫水 したるのは特に溶解する此方法を用ふれば低燐鐵鏣を得ることが出來る。8. $1,000^{\circ} \mathrm{C}$ に於て一酸化炭 素にて急速に還元すれば嶙分の約 $50 \%$ 或はそれ以上が揮發する。9.硫黃は主として硫酸礝として存 在し之は訫性加里液又は溫湯に溶解する此硫带は大氣中にて $900^{\circ} \mathrm{C}$ 飞於て殆んど全部揮發する。10. $800^{\circ} \mathrm{C}$ 或はそれ以上の加熱に体り沼鐵鎦の性質は著しく變化する此溫度に焙燒したものは水分を吸收 する能力なく赤鐵鑛と同栐な性質を持入梯になる。

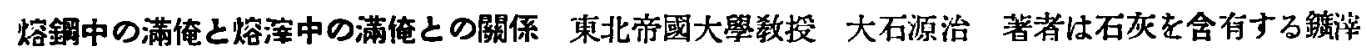
と含有せざるすのとに就て其含有湔俺分と其と共存する熔銅中の滿仵分との間に成立する關係を實驗 室的に研究し更に之を實際平曥作業に就て筫驗し。之に陆つて平爐製鋼作業を述べたものである。

鐵鐿石還元に於ける物理化暴 杉本物吉 $6 \mathrm{Fe}_{2} \mathrm{O}_{3}=4 \mathrm{Fe}_{3} \mathrm{O}_{4}+\mathrm{O}_{2}$ 反應系に於ける酸素の分壓化就て 諭じ且大氣中に於て $\mathrm{Fe}_{2} \mathrm{O}_{3}$ の $\mathrm{Fe}_{3} \mathrm{O}_{4}$ 汇分解する溫度を計算した。雨他の酸化鐵の分解溫度を計算し た。 其他此等の系の親和力と溫度との關係。 $2 \mathrm{CO}=\mathrm{C}+\mathrm{CO}_{2}$ 反應系。酸化鐵の一酸化炭素に传る還元 等に就て述べ最後に還元速度に就て諭じて居る。

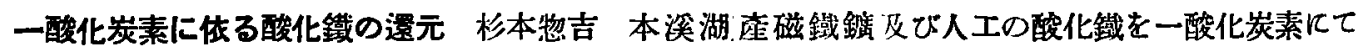

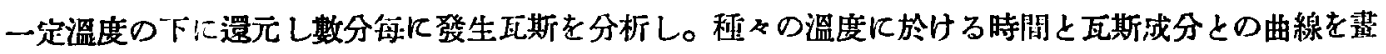
き之に依つて酸化鐵つ還元反隹を考察したものでする。

(田 中)

固相線以下に起る黑鉛化 米國ナショナル鋠物會社研究部長 H. A. Schwartz 固相線以下の一定 溫度に起る品鉛化の現象を時間と黑鉛量との䦌の關係式に体つて品鉛化の現象の說明を試みた。郎ち

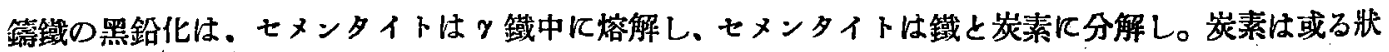
態に於て固溶鳢中を移動する。而して或る核を中心として結晶すると云ふ假定を證明した。 


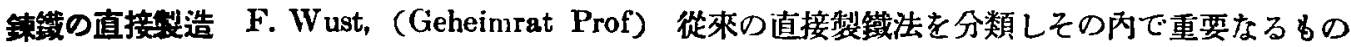
に就て简品に說朋し且經济的方面より比較考察したものである。如何なるものも艮好な方法でないが その內で固體の鐵と固體の鍈滓を得る方法は最も經濟的であると。

(出 中)

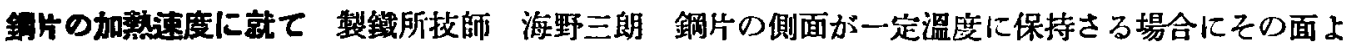
り種ふの距雜に於ける點が或一定の溫度に達する迄の時間を熱傳導式より理論的に計算し且實驗の結 果から鋼片の厚さと、加熱時間。然料の消貸量及び單位時間に加熱さるる銅片の量等との間の關係を 求めたもので放る。 (时中)

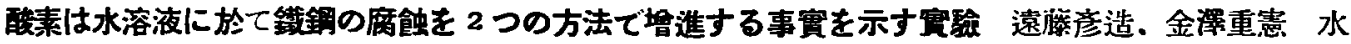

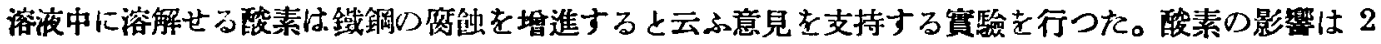
段作用する。今鐵の 1 片を水中に请けると先づ第 1 段に於て鐵の少量は第一鐵イオンとして溶液に 入り。之が溶解せる酸素の漂淡電池の生成により堽進せられる。第一鐵イォンか出来て水素イォンの 當量が其荷電を失ふと此の水素は鐵の表面に遊蜼水素の薄腅としこ沈潑する。而して第2段に於て酸 素が水中にあれば第一酸化鐵が酸化されて 含水第二酸化鐵師ち錆となり水素膜は酸化されて消隇す

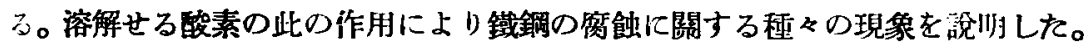

(室 井)

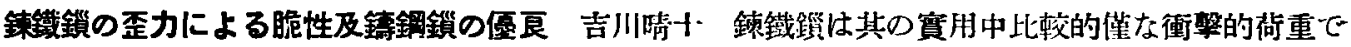

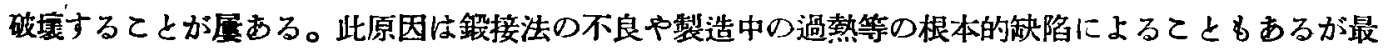
も注意を要するのは使用中の荷重或は使用前の試驗荷重による材料の脆化作用である。鐵鑬の試驗規 格には其の材料の破断荷重の約 $72 \%$ にも相當する張力に堪ゆへしと云ふのがある。けれども鉠鐵は 或限界以上の力を掛けると脆くなり其アイシツド衝撃值恃原値の $1 / 3$ に減少するととすらある。斯る

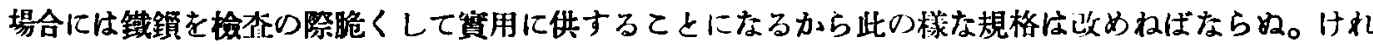
ども此の樣な脆性は適當の憢鈍により除去するてとが出來るから現規格の存する限は燒鈍法を規定す るととが必要じある。

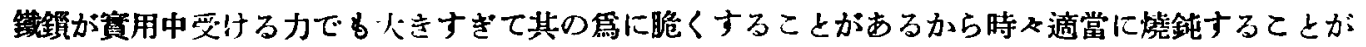
必要である。

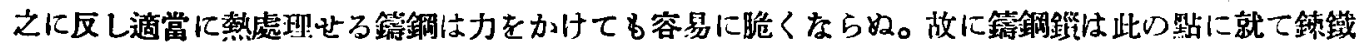

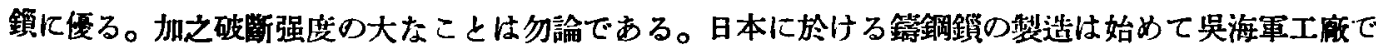

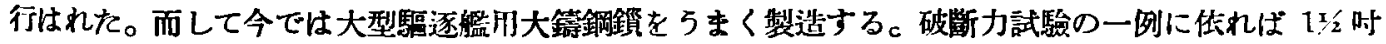

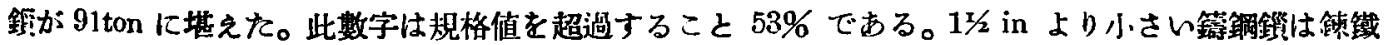
皟より高價であるが、之より大いものは安く出來る。

(空 井)

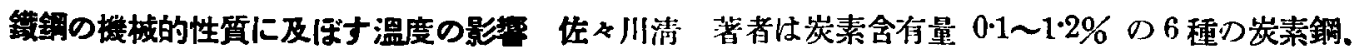

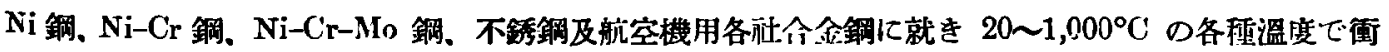




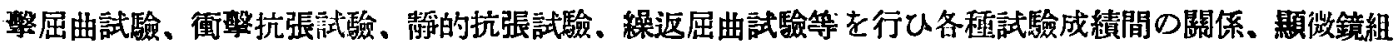
織と機栈的性質の關係等を研究し．且つ青熱脆性に對し一つの說明を與へた。

(室. 井)

無烧監類の水溶液中に於ける銅の腐蝕に就て 福村賢三 本研究は $\mathrm{NaCl}, \mathrm{Na}_{2} \mathrm{SO}_{4}, \mathrm{NaNO}_{3}$, $\mathrm{Na}_{2} \mathrm{CO}_{3}, \mathrm{NaHCO}_{3}, \mathrm{NH}_{4} \mathrm{Cl},\left(\mathrm{NH}_{4}\right)_{2} \mathrm{SO}_{4}, \mathrm{NH}_{4} \mathrm{NO}_{3},\left(\mathrm{NH}_{4}\right)_{2} \mathrm{CO}_{3}, \mathrm{CaCl}_{2}$ 及 $\mathrm{CaSO}_{4}$ の各種監類の

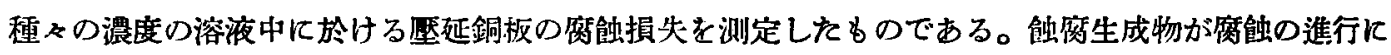
及卧す影碎を研究してある。 (室 井)

治金工業に於ける動カ 米國ブラスラート治金技師 Robert M. Keeney 近年米國にて著しき發展 を來せしは冶金工業て對する電力の應用にして就中重要なる者は，大規模の金屬抵抗爐に依る鐵及び

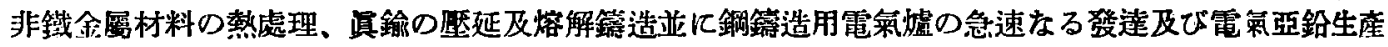

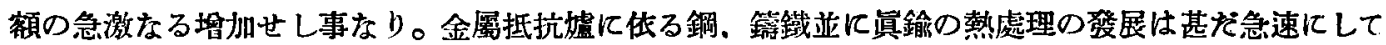

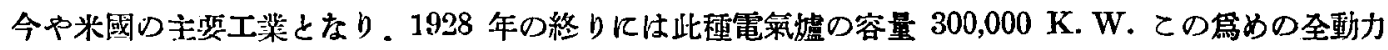

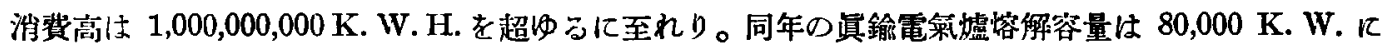

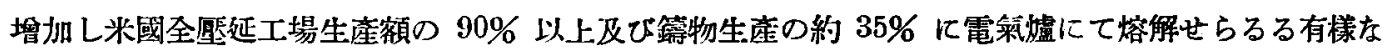

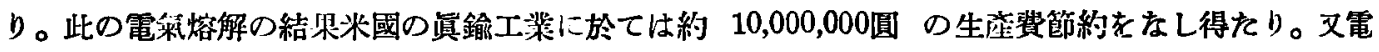

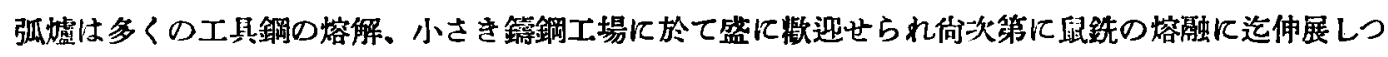
つすり。電䈀亞鉛の生產も亦急速に增大し Anaconda Copper Mining Co. のみにても 1928 年に於て

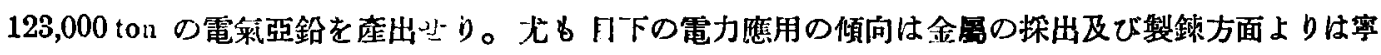
ろ金屬の製造．加工及び仕上の方面に向ひて著しき發展を來しつつある将樊なり。以上の如く治金工 業に於ける電力は米國の工業發展に於て極て重要なる要素と成れり。

满俺銅と其發達 Sir Robert A. Hadfield, Manager of Roya! Institution; Chairınan and Managing Directer of Hadfields Itd. 著者は㴖俺銅が工業上重要なる位置を占めつつある事を指摘すると共K

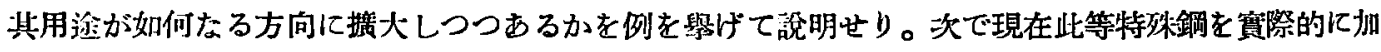

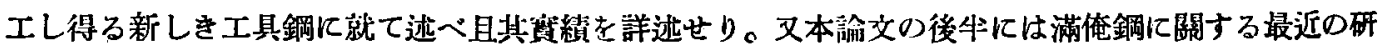
究並に此等の研究が本鋼の獨特にして且侕値ある諸性質の根元に閶して與へたる正しき智識を評論せ b。

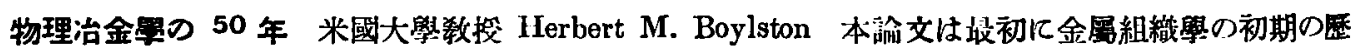
史並K HI. C. Sorby, Henry Marion Howe 及 Albert Sauveur の3博士が此の新しき學問の開發

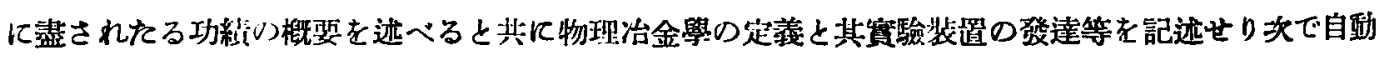

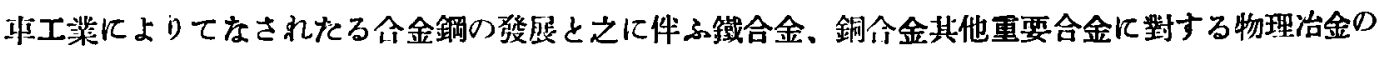

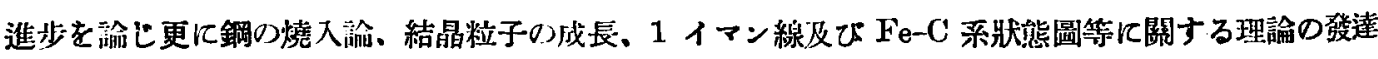
を記迅せり。而して樶後には米國標潐局、東北帝國大學金屬材料研究所、American Society for Steel 
Treating の設立と Transaction of American Institute of Mining \& Metallmgical Engineering, 英 國の Iron and Steol Institute, 同 Institute of Metals 等が斯界に於て重要なる位置に在る事业を詳述 せり。

新しき货需用合金 京都帝國大學教授 理學坟士 近重真澄 上野修三 現今使用せらるる銀貨の 地金は、銀の含有量を出來得る限り少くせむとする世界的傾向を示す以外には何等特别の意義を有せ

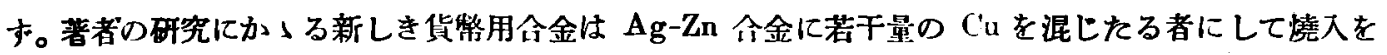
行ふ事に上りて其顯微鏡的組織及び硬度を變するを以て分析を行ふてとをくして簡單に其の㩐造を看 出する事を得べし。而してCu の添加は本合金の機械的性質並に䇺造性を改䪧するの效ある者なり。

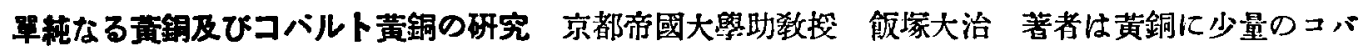
ルトを混したる場合の影響を明汃にせとて本研究を企て遂に Cu 50〜100\%，Zn 0 50\%，Co 0 10\%の範園に於りる三元系行衡可を作咸せり。而して 1〜2\%のCのの添加は 60:40 黃銅の抗張力 並に延伸率を改善し、且Co 3〜4\% の添加によりてネバルブラスと同樣に海水の腐蝕に對する抵抗性 を有せしむる事を得たり。Cu〜Co 二元系に關してはSahman 氏の平衡圖に若干の修正を加ふへき必 要あるてよを認めたり。

瑞典鐵製造法 J. A. I Jefler 本論文は次の事項を記す 1. 緒言 2. 燃料 3. 鋺石 4. 海綿鐵

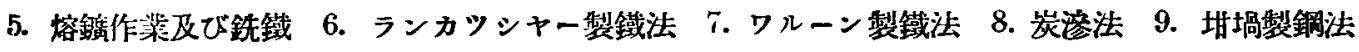

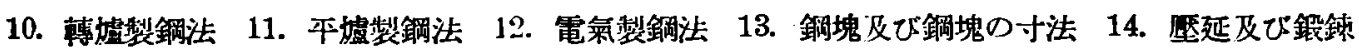
15. 瑞典製鐵業組合 16. 探鈸冶金礐會 17. 金屬研究所並に試驗所

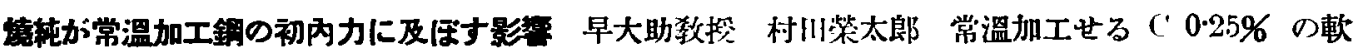
銅棒に存する初內力が加熱溫底、加熱時間亚に時效により如何に變化するかをZeiss のオプテイメー ターを用し Heyn の方法に依つて測定し次の結果を得た。

1. 常溫に於ける時效による初內力の減少は加工後約 20 日冈に於て著しく其後徐たとなる。

2. 加熱時間に關しては最初の 30 分內に著しく減じ其後徐々となり $350 〜 500^{\circ} \mathrm{C}$ 殊に 400 ( : に於 ては 8 時間以內では相當大なる減少率を有す。

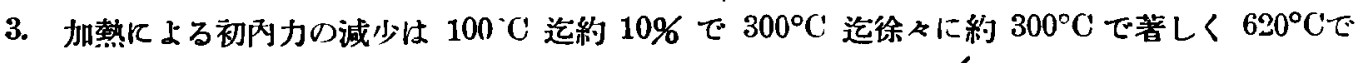
完全に除去さる。

以上の結果より著者は $300^{\circ} \mathrm{C}$ 迄の減少は吅熱の雹め原子運動が旺盛になつたてとに原因し 300〜 $600^{\circ} \mathrm{C}$ の減少は常溫加工銅の北結晶に殓因するるのとせり。

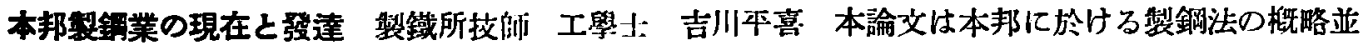

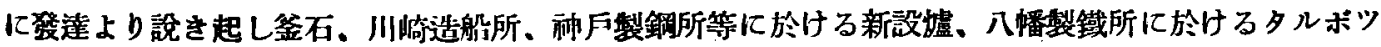

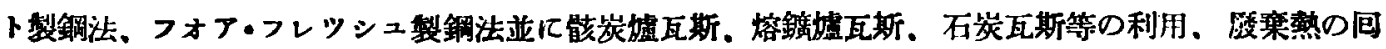




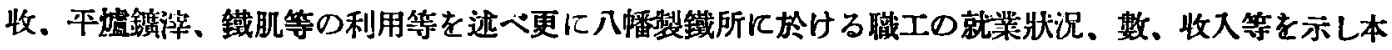
邦彆鋼業の现在上將來を論す。

熱風の意義及び熔簧㠊の生座高に及ぼす影嚮 F. W uest 本論文は Neilson が 100 年前熱風を利 用し始めたる時より今日に至る迄の徑過を概說し熱風使用に体る爈況の改善、燃料消費量の減少。生

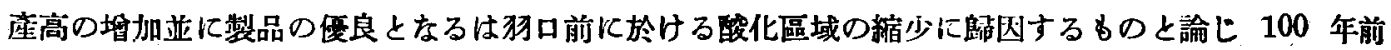
と今日に於ける操業成䌒を次の如く比較し今日の成績良好なるは主として熱風使用の發見にありと絬 論す。

\begin{tabular}{|c|c|c|}
\hline 生花高 24 時問 (t) & $\begin{array}{l}1829 \\
2 \sim 10\end{array}$ & $\begin{array}{c}1929 \\
200 \sim 1,000\end{array}$ \\
\hline 生高堵の內窟 $(t)$ & $0.01 \sim 0.1$ & $0.5 \sim 10$ \\
\hline 銫石下降時間（時） & 60 & $8 \sim 15$ \\
\hline 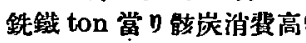 & (t) $2 \cdot 5 \sim 4.0$ & $0.8 \sim 1.2$ \\
\hline 銑践 ton 當り逯風量 $\left(\mathrm{m}^{3}\right.$ & $10,000 \sim 12,000$ & $2, \mathbf{4} 00 \sim 3,000$ \\
\hline 选風盢度 $\left(^{\circ} \mathrm{C}\right)$ & 20 & $700 \sim 800$ \\
\hline 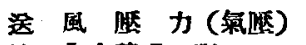 & $0.05 \sim 0.1$ & $0.3 \sim 1.0$ \\
\hline 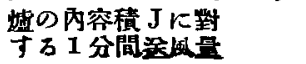 & $0.2 \sim 0.3 \times \mathrm{J}$ & $1 \cdot 0 \sim 2 \cdot 2 \times J$ \\
\hline 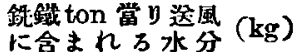 & $200 \sim 240$ & $48 \sim 60$ \\
\hline 坡頂に於け万㵋度 $\left({ }^{\circ} \mathrm{C}\right)$ & 500 & $150 \sim 200$ \\
\hline 五斯の客 $\left(\mathrm{m}^{3}\right)$ & $12,000 \sim 15,000$ & $2,900 \sim 4,300$ \\
\hline 装入物と骵崖の此 & $1: 4 \sim 1: 5$ & $1: 1 \cdot 5$ \\
\hline 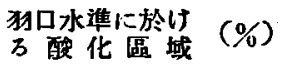 & 粎 95 & 粎 50.65 \\
\hline
\end{tabular}

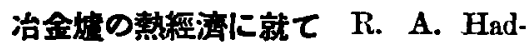
field and R. T. Sarjant 冶金嘘の荷重が

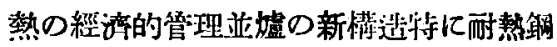
を機械裝置嘘に應用した場合其影響を如 何に研究ずべか老諭じ然料供給速度の 調節特に白働調節法の利點を數量的に表

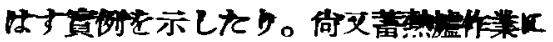
對する耐熱銅の應用を論じ石炭焚火譃の 第一次空莱の加熱に應用して好成樍支る 事を述へ、終りに蓄熱㠊に於ける熱流の 研究並に可動蓄熱嘘に於ける耐熱合金使 用の可能性を暗示せり。

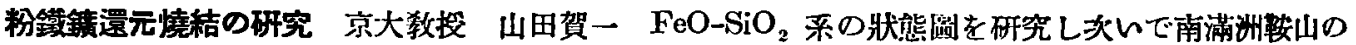

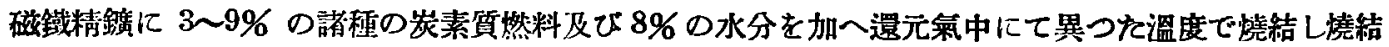
鎐の物理的及び化學的試驗を行ひ更に諸國の製鐵所に於て大規模に造つた燒結鑛 5 種を取り其物理的

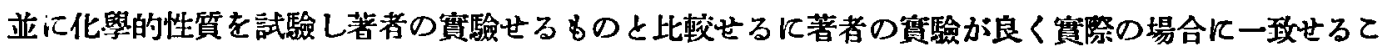
と老登明し次の結論に達せり。

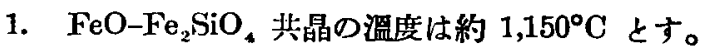

2. 還元氣中に於ける燒結は酸化氣中に於けるものに勝る。

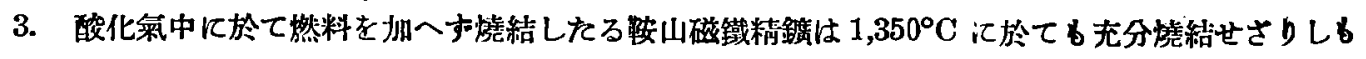

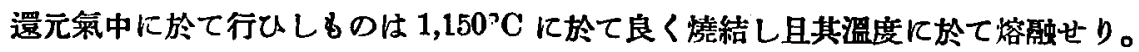

4. 粉鐵鍍の憢結溫度は共揢骶點により異なり其揢骶點に出來る限り近き溫度に於て烧結するを良 しとす而して塎融點に於て暫時加熱するも瓦斯の發生により適當の有孔性を失ふてとなし。

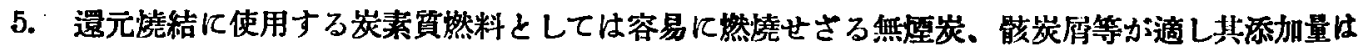

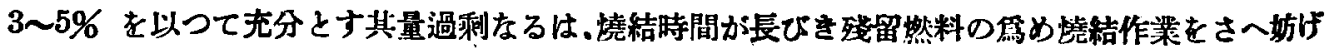


らる。

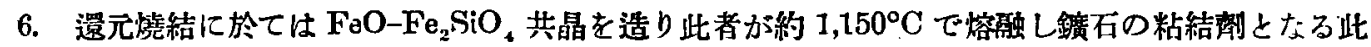
事實はフランクの牛熔融說又はグレンダルの結晶說に依る酸化燒絬に於て得られで結果と全く異 なる。

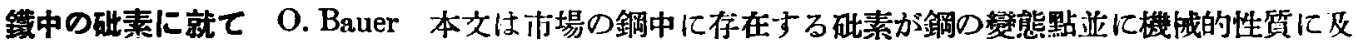
任す影響を述べたるものである。

市場の鋼中に含まれる䂤素は通常0.02〜0.05\%にして此程度に於ては完全に鐵に溶解し $\mathrm{Ar}_{3},, \mathrm{Ar}_{2}$, $\mathrm{Ar}_{1}$ 等は䂤素 0-11\% 迄は影響を受け一。

靜的試驗は砒素 $0.11 \%$ 存在するも影響なく常溫（約 $20^{\circ} \mathrm{C}$ ) に於ける重的試驗には稍々影響を有し 打擊に對する抵抗力を明か汇娍するも $0.02 〜 0.05 \%$ の程度にては其影響を極めて僅か認めるに過ぎ \&2。

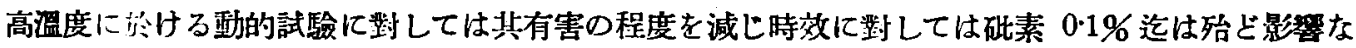
L。

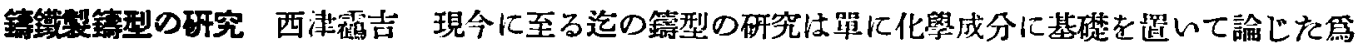

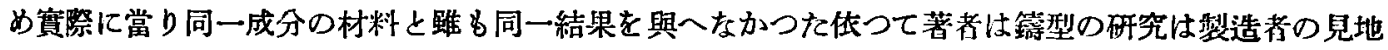

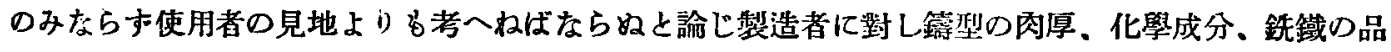

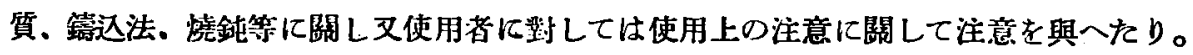

熔接に就て 本論文は熔接に關して多くの著者が發表せるものを一集めにしたもので熔接法、熔接 器具、諸蒩の應月等が記械さる。

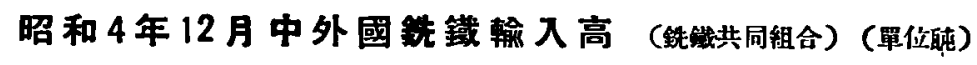

\begin{tabular}{|c|c|c|c|c|c|c|c|c|c|c|}
\hline \multicolumn{3}{|c|}{ 签出圈入敕入港 } & 横 演 & 㱚 F & 大 阪 & 門 司 & 咕古庫 & 其 地 & 計 & \multirow{2}{*}{$\begin{array}{c}1 \text { 月以瀿 } \\
\text { 話 } \\
2,122\end{array}$} \\
\hline 支 & & 那 & - & - & - & - & - & - & - & \\
\hline 印 & & 度 & 5,350 & 2,287 & 10,864 & $2,16 J$ & 205 & - & 20,866 & 414,773 \\
\hline 英 & & 国 & 103 & - & - & - & - & 51 & 154 & 9,204 \\
\hline 誼 & & 造 & - & - & - & - & - & - & - & 4,628 \\
\hline * & & 國 & - & - & - & - & - & - & - & (3),717 \\
\hline 瑞 & & 典 & - & - & - & - & - & - & - & 821 \\
\hline 白 & 耳 & 舱 & 307 & - & - & - & - & - & 307 & 307 \\
\hline 其 & & 他 & - & - & 5 & - & - & - & 5 & 5 \\
\hline & 計 & & 5,760 & 2,287 & 10,969 & 2,160 & 205 & 51 & 21,332 & 462,577 \\
\hline & & 橵考 & 辛程层 & EO数 & 單位诚 & 以下 & & & & \\
\hline
\end{tabular}




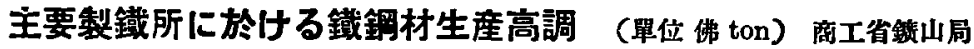

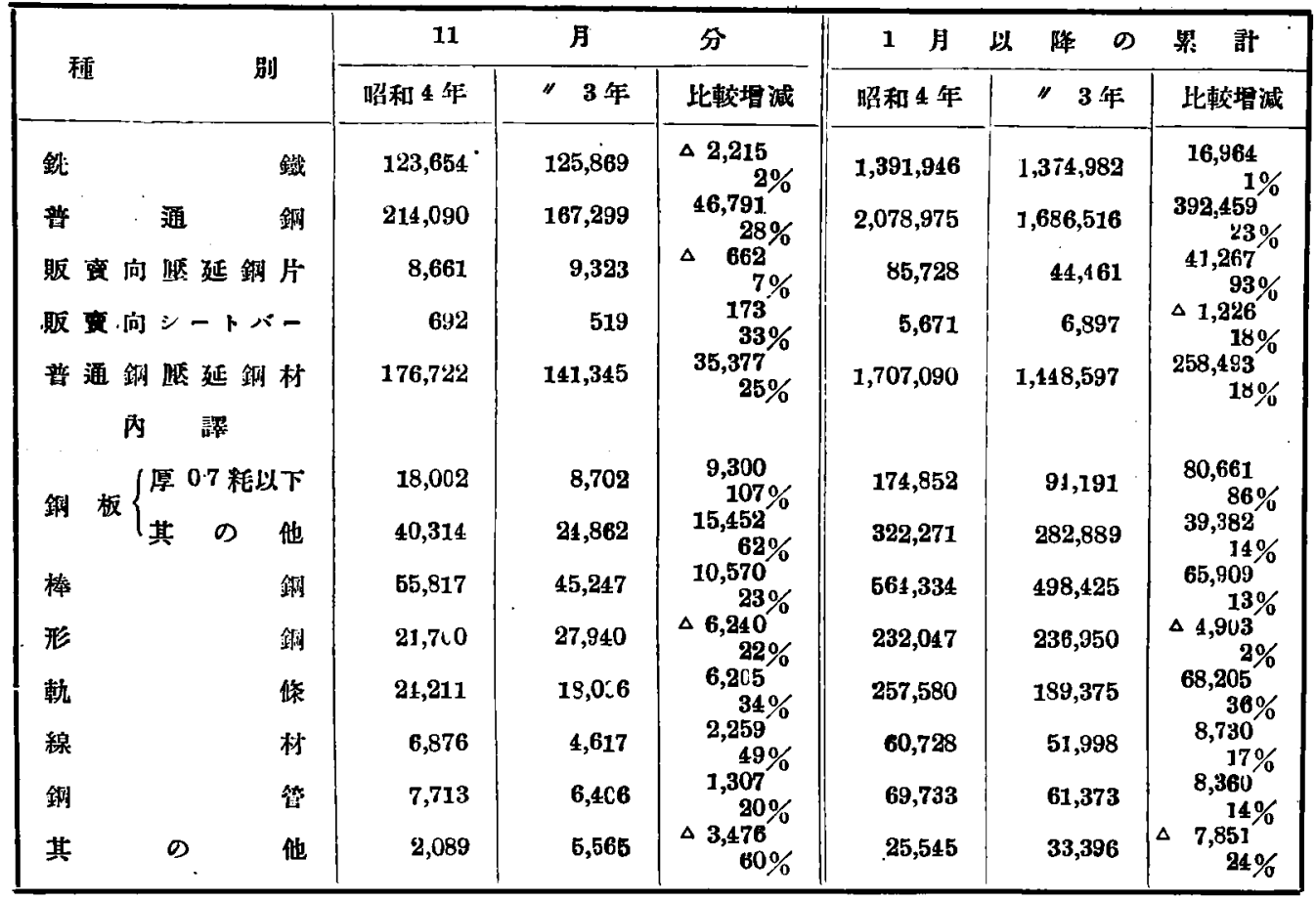

昭和 5 年 1 月中(八幡)製鐵所銑鎆生座高表(醋)

\begin{tabular}{|c|c|c|c|c|c|c|c|c|}
\hline 銑 & & 鐵 & 銅 & & 塊 & 銅 & & 材 \\
\hline 當月生应高 & 前月此較 & 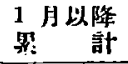 & 當月生产高 & 前月比暧 & $\begin{array}{l}\text { 1月 以除 } \\
\text { 男 }\end{array}$ & 當月生应高 & 前月比較 & 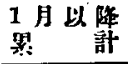 \\
\hline 62,166 & $+1,848$ & & 111,183 & $-1,900$ & & 95,780 & $-5, \mathbf{4 6 0}$ & \\
\hline
\end{tabular}

